IDAHO NATIONALENGINEERING LABORATORY

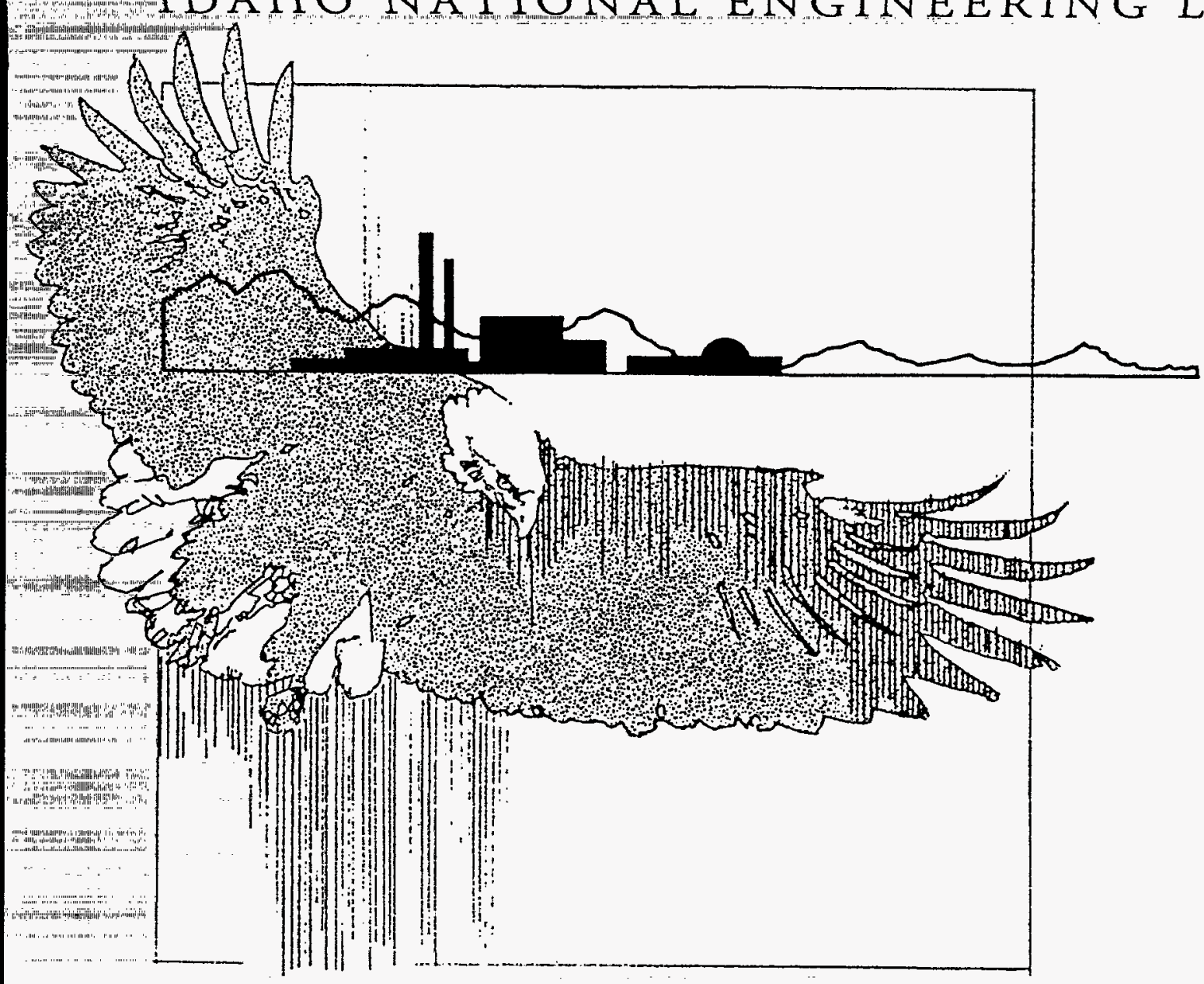

INEL-95/0048

\title{
Markets for Reactor-Produced Non-Fission Radioisotopes
}

January 1995

R. G. Bennett

DISCLAIMER

This report was prepared as an account of work sponsored by an agency of the United States Government. Neither the United States Government nor any agency thereof, nor any of their employees, makes any warranty, express or implied, or assumes any legal liability or responsibility for the accuracy, completeness, or usefulness of any information, apparatus, product, or process disclosed, or represents that its use would not infringe privately owned rights. Reference herein to any specific commercial product, process, or service by trade name, trademark, manufacturer, or otherwise does not necessarily constitute or imply its endorsement, recommendation, or favoring by the United States Government or any agency thereof. The views and opinions of authors expressed herein do not necessarily state or reflect those of the United States Government or any agency thereof.

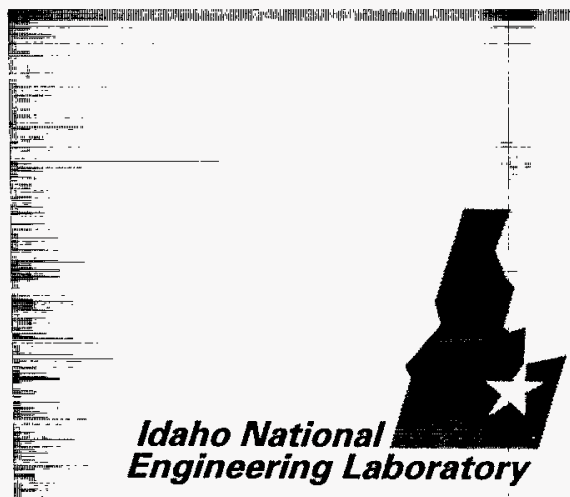

\section{MASTER}

Work performed under DOE Contract No. DE-AC07-94ID 13223 


\section{DISCLAIMER}

Portions of this document may be illegible in electronic image products. Images are produced from the best available original document. 


\title{
Markets for Reactor-Produced Non-Fission Radioisotopes
}

\author{
Dr. Ralph G. Bennett \\ Idaho National Engineering Laboratory
}

\section{January 1995}

Prepared for the U.S. Department of Energy through the INEL LDRD Program under DOE Idaho Operations Office Contract DE-AC07-94ID13223 


\begin{abstract}
Current market segments for reactor produced radioisotopes are developed and reported from a review of current literature. Specific radioisotopes studied in this report are primarily selected from those with major medical or industrial markets, or those expected to have strongly emerging markets. Relative market sizes are indicated. Special emphasis is given to those radioisotopes that are best matched to production in high flux reactors such as the Advanced Test Reactor (ATR) at the Idaho National Engineering Laboratory or the High Flux Isotope Reactor (HFIR) at the Oak Ridge National Laboratory. A general bibliography of medical and industrial radioisotope applications, trends, and historical notes is included.
\end{abstract}




\section{Contents}

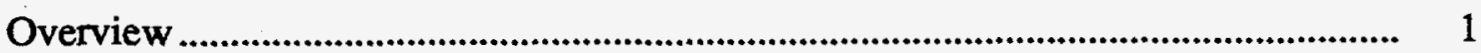

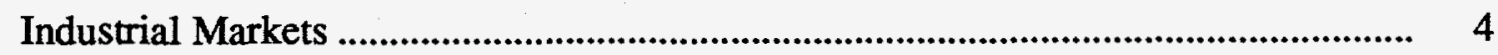

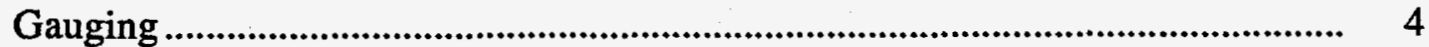

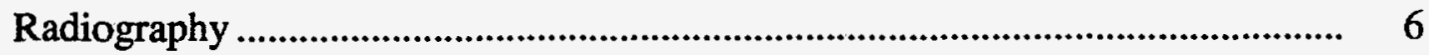

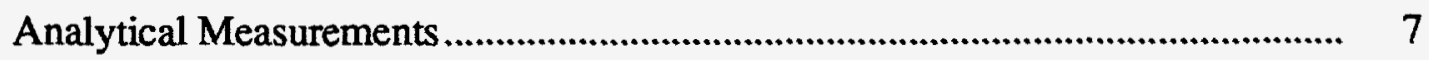

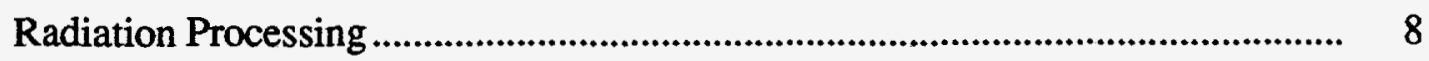

Heat and Lighting Sources ...................................................................... $\quad 10$

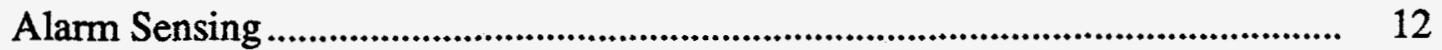

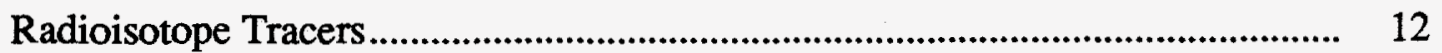

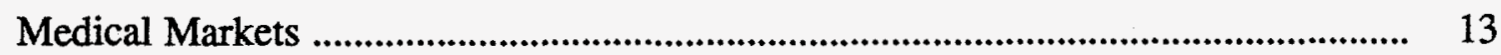

Brachytherapy and External Beam Therapy ................................................ 13

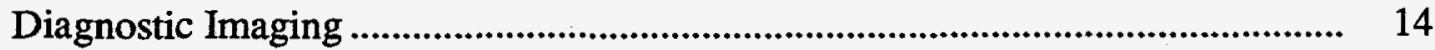

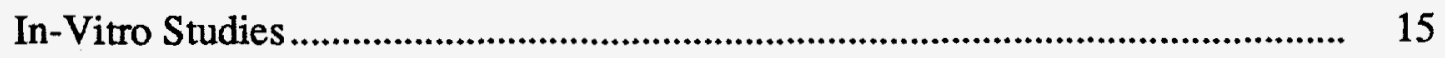

Unsealed Source Therapies ........................................................................ 16

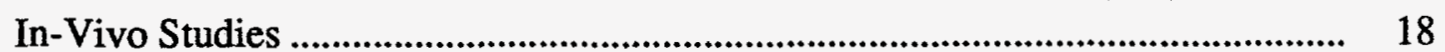

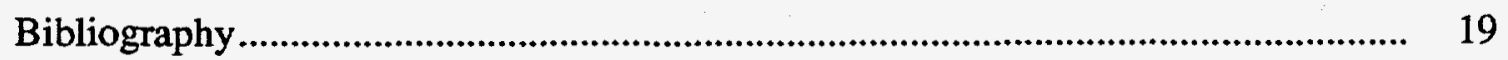




\section{Markets for Reactor-Produced Non-Fission Radioisotopes}

\section{Overview}

This report presents the current status of applications and markets relevant to production of radicisotopes, other than fission products, in high flux nuclear reactors. Some two dozen isotopes were studied in detail and are discussed here. The criteria for their inclusion were generally that the radioisotope:

- Possess, or be predicted to grow into, a fairly large market in the U.S.

- Be a reasonably good fit for production in a high flux reactor such as the Advanced Test Reactor (ATR) or High Flux Isotope Reactor (HFIR)

- Not already have a domestic source sufficient to supply the demand.

The discussion emphasis is weighted much more strongly to those radioisotopes that are considered good candidates for production. The four radioisotopes currently produced in significant quantities at the ATR and/or HFIR (Ir-192, Co-60, Cf-252, and Ni-63) were not extensively studied since their supply and market need are already familiar. Market entry of Mo-99 or other fission product radioisotopes would present unique problems in the U.S.; these radioisotopes are omitted from this report for brevity.

The radioisotopes studied included the following:

$\begin{array}{ccc}\text { Au-198 } & \text { Cd-109 } & \text { Co-58 } \\ \text { Cu-67 } & \text { Fe-55 } & \text { Fe-59 } \\ \text { Gd-153 } & \text { Ho-166 } & \text { I-125 } \\ \text { Os-191 } & \text { P-32 } & \text { P-33 } \\ \text { Pd-103 } & \text { Po-210 } & \text { Re-186 } \\ \text { Se-75 } & \text { Sm-145 } & \text { Sm-153 } \\ \text { Sn-117m } & \text { Sr-89 } & \text { Tl-204 } \\ \text { Tm-170 } & \text { W-188 } & \text { Yb-169 }\end{array}$

Other radioisotopes, including some fission products, appear in this report mainly for comparison or as background information

It should be noted that market conditions can change rapidly, especially for newly emerging radioisotopes, so that the relative rankings provided in this report could change markedly with time. This report provides current information in a format that may serve as a useful framework for continued study.

A useful compilation of radioisotope data is presented in Table 1 for groupings of alpha-particle, positron, and beta-particle emitters. The beta emitters are arranged in ascending order of the energy of their beta particle. Compilations of $\mathrm{x}$-ray, conversion 
electron (e-), and gamma-ray emitters is presented in Table 2. They are arranged in ascending order of the energy of the photon or conversion electron emitted, whichever is deemed to be the primary attribute of interest for the radioisotope in question.

Table 1. Principal Radiation of Selected $\alpha, \beta+$, and $\beta$ - Emitters.

\begin{tabular}{|c|c|c|c|c|}
\hline $\begin{array}{c}\text { Nuclide } \\
\text { Parent/Daughter }\end{array}$ & $\begin{array}{l}\text { Half-Life } \\
\text { (days) }\end{array}$ & $\begin{array}{l}\text { Principal } \\
\text { Radiation }\end{array}$ & $\begin{array}{c}\text { Energy* } \\
(\mathrm{keV})\end{array}$ & $\begin{array}{c}\text { Abundance } \\
(\%)\end{array}$ \\
\hline Po-210 & 138.4 & $\alpha$ & 5304 & 100 \\
\hline Co-58 & 70.9 & $\begin{array}{c}\beta+ \\
\gamma\end{array}$ & $\begin{array}{c}30 \\
810.8\end{array}$ & $\begin{array}{c}15 \\
100\end{array}$ \\
\hline $\mathrm{Na}-22$ & 951.5 & $\beta+$ & 195 & 89 \\
\hline Ni-63 & 36,562 & $\beta-$ & 17.1 & 100 \\
\hline P-33 & 25.34 & $\beta-$ & 76 & 100 \\
\hline $\mathrm{Cu}-67$ & 2.580 & $\begin{array}{c}\beta- \\
\gamma \\
\gamma\end{array}$ & $\begin{array}{c}142 \\
184.6 \\
93\end{array}$ & $\begin{array}{l}100 \\
49 \\
23\end{array}$ \\
\hline $\mathrm{I}-131$ & 8.040 & $\beta-$ & $\begin{array}{c}182 \\
364.5\end{array}$ & $\begin{array}{l}100 \\
81\end{array}$ \\
\hline Sm-153 & 1.95 & $\begin{array}{c}\beta- \\
\gamma \\
x-r a y\end{array}$ & $\begin{array}{c}225 \\
103.2 \\
42\end{array}$ & $\begin{array}{l}100 \\
28 \\
32\end{array}$ \\
\hline T1-204 & 1380 & $\beta-$ & 238 & 98 \\
\hline $\mathrm{Tm}-170$ & 128.6 & $\beta-$ & 315 & 100 \\
\hline $\operatorname{Re}-186$ & 3.777 & $\beta-$ & $\begin{array}{l}323 \\
137\end{array}$ & $\begin{array}{c}100 \\
9\end{array}$ \\
\hline Au-198 & 2.694 & $\begin{array}{c}\beta- \\
\gamma\end{array}$ & $\begin{array}{r}406 \\
411.8\end{array}$ & $\begin{array}{l}100 \\
96\end{array}$ \\
\hline Dy-165 & 0.0973 & $\stackrel{\beta-}{\gamma}$ & $\begin{array}{c}442 \\
95\end{array}$ & $\begin{array}{c}100 \\
4\end{array}$ \\
\hline $\mathrm{Sr}-89$ & 50.55 & $\beta-$ & 583 & 100 \\
\hline $\mathrm{P}-32$ & 14.28 & $\beta-$ & 695 & 100 \\
\hline Ho-166 & 1.117 & $\begin{array}{c}\beta- \\
\gamma\end{array}$ & $\begin{array}{l}711 \\
80.6\end{array}$ & $\begin{array}{c}100 \\
6\end{array}$ \\
\hline W-188/Re-188 & $69.4 / 17 \mathrm{~h}$ & $\begin{array}{c}\beta- \\
\gamma-\end{array}$ & $\begin{array}{c}765(\mathrm{D}) \\
155(\mathrm{D}) \\
99\end{array}$ & $\begin{array}{l}100 \\
15 \\
100\end{array}$ \\
\hline
\end{tabular}

* Average beta decay energies are given. Symbol (D) signifies daughter radiation. 
Table 2. Principal Radiation of Selected $x$-ray, $e$-, and $\gamma$-ray Emitters.

\begin{tabular}{|c|c|c|c|c|}
\hline $\begin{array}{c}\text { Nuclide } \\
\text { Parent/Daughter }\end{array}$ & $\begin{array}{c}\text { Half-Life } \\
\text { (days) }\end{array}$ & $\begin{array}{l}\text { Principal } \\
\text { Radiation }\end{array}$ & $\begin{array}{c}\text { Energy* } \\
(\mathbf{k e V})\end{array}$ & $\begin{array}{c}\text { Abundance } \\
(\%)\end{array}$ \\
\hline $\mathrm{Fe}-55$ & 997.1 & $x$-ray & 6 & 16 \\
\hline Pd-103/Rh-103m & $16.97 / 56 \mathrm{~m}$ & $\begin{array}{c}x-r a y \\
\gamma\end{array}$ & $\begin{array}{c}21 \text { (D) } \\
39.8 \text { (D) }\end{array}$ & $\begin{array}{c}42 \\
0.07\end{array}$ \\
\hline Cd-109/Ag-109m & $462 / 40 \mathrm{~s}$ & $\begin{array}{c}x \text {-ray } \\
\text { conversion e- } \\
\gamma\end{array}$ & $\begin{array}{c}22 \\
81(D) \\
88 \text { (D) }\end{array}$ & $\begin{array}{c}55 \\
40 \\
4\end{array}$ \\
\hline $\mathrm{I}-125$ & 60.14 & $\begin{array}{c}\text { conversion e- } \\
\text { conversion e- } \\
x-\text { ray } \\
\gamma\end{array}$ & $\begin{array}{l}4 \\
31 \\
27 \\
35\end{array}$ & $\begin{array}{c}158 \\
11 \\
76 \\
7\end{array}$ \\
\hline Sn-117m & 13.61 & $\begin{array}{c}\text { conversion e- } \\
\gamma\end{array}$ & $\begin{array}{c}127 \\
158.6\end{array}$ & $\begin{array}{l}66 \\
86\end{array}$ \\
\hline Sm-145 & 340 & $\begin{array}{c}\gamma \\
x \text {-ray } \\
x-\text { ray }\end{array}$ & $\begin{array}{c}61 \\
38.7 \\
44\end{array}$ & $\begin{array}{l}12 \\
74 \\
21\end{array}$ \\
\hline Gd-153 & 241.6 & $\begin{array}{c}x-r a y \\
\gamma \\
\gamma\end{array}$ & $\begin{array}{c}42 \\
97.4 \\
103.2\end{array}$ & $\begin{array}{l}62 \\
28 \\
20\end{array}$ \\
\hline Yb-169 & 32.02 & $\begin{array}{c}\gamma \\
\gamma \\
x-r a y\end{array}$ & $\begin{array}{c}63.1 \\
198 \\
51\end{array}$ & $\begin{array}{l}44 \\
35 \\
94\end{array}$ \\
\hline Os-191//r-191m & $15.4 / 5 \mathrm{~s}$ & $\underset{x-r a y}{\gamma}$ & $\begin{array}{c}129.4(\mathrm{D}) \\
65(\mathrm{D}) \\
37.5\end{array}$ & $\begin{array}{l}26 \\
28 \\
100\end{array}$ \\
\hline I-123 & 0.5504 & $\underset{x-r a y}{\gamma}$ & $\begin{array}{l}159 \\
27.5\end{array}$ & $\begin{array}{l}83 \\
47\end{array}$ \\
\hline $\mathrm{Se}-75$ & 119.8 & $\begin{array}{c}\gamma \\
\gamma \\
x-r a y\end{array}$ & $\begin{array}{c}265 \\
136 \\
10\end{array}$ & $\begin{array}{l}59 \\
59 \\
32\end{array}$ \\
\hline Ir-192 & 73.83 & $\begin{array}{c}\gamma \\
\gamma \\
\beta-\end{array}$ & $\begin{array}{c}468 \\
316.5 \\
171\end{array}$ & $\begin{array}{l}48 \\
83 \\
95\end{array}$ \\
\hline Cs-137 & 10,968 & $\stackrel{\gamma}{\beta-}$ & $\begin{array}{l}662 \\
188\end{array}$ & $\begin{array}{l}85 \\
100\end{array}$ \\
\hline $\mathrm{Fe}-59$ & 44.5 & $\begin{array}{c}\gamma \\
\gamma \\
\beta-\end{array}$ & $\begin{array}{l}1100 \\
1300 \\
118\end{array}$ & $\begin{array}{l}57 \\
43 \\
100\end{array}$ \\
\hline $\mathrm{Co}-60$ & 1,925 & $\begin{array}{c}\gamma \\
\gamma \\
\beta-\end{array}$ & $\begin{array}{c}1333 \\
1173 \\
96\end{array}$ & $\begin{array}{l}100 \\
100 \\
100\end{array}$ \\
\hline
\end{tabular}

* Average beta decay energies are given. Symbol (D) signifies daughter radiation. 


\section{Industrial Markets}

\section{Gauging}

Industrial radioisotope gauging comprises a broad set of methods for determining the thickness, concentration, density, or weight of a product undergoing continuous production. Gauging methods can measure the total product thickness, as for sheets of film or paper, or the coating thickness on a workpiece, as in spray painting, etc. Special methods include the measurement of moisture content with neutron scattering or the simultaneous measurement of both the impurity levels and thickness of cigarette paper. Special geometries have been treated, for example, in down-hole well logging where the region measured is not planar, and in tube thickness gauging.

The radiation employed very generally includes beta particles, gamma rays, and to a lesser extent, alpha particles and neutrons. A summary of the major radioisotopes is shown in Table 3, where the entries are categorized by the type of radiation. Generally, the beta-particle emitters are the most commonly used because the range of beta particles in solids is comparable to typical sheet thicknesses. The gamma emitters are the next most commonly used.

Detection methods vary widely in industrial gauging. The most popular methods are beta transmission (for thin samples) and beta backscatter (for measuring from one side). Similar techniques are used for gamma rays, and special geometries have been developed, for example, in providing a wide beam to 'weigh' (i.e., measure the net mass flow of) the contents of a moving belt of ore or other product. Sometimes gauging detection methods are combined with analytical methods to provide simultaneous measurements of both geometry and composition, especially for laminated structures of differing atomic numbers.

In general, radioisotope gauging provides a very rapid on-line, non-destructive and noncontacting measurement. The sources can usually be chosen to give a long lifetime between changeout. Radioisotope gauging is a steady market for radioisotopes. 


\begin{tabular}{|c|c|c|}
\hline Radioisotope & Relative Use & Comments \\
\hline & & Alpha emitters \\
\hline Am-241 & Moderate & Alpha particle source. Long 433 year half-life. \\
\hline Po-210 & Very Low & $\begin{array}{l}\text { Alpha particle source. Short } 4.5 \text { month half-life. } \\
\text { Beta emitters }\end{array}$ \\
\hline $\mathrm{Kr}-85$ & High & $\begin{array}{l}\text { Beta particle source with } 0.67 \mathrm{MeV} \text { maximum energy. Moderate } \\
10.6 \text { year half-life. Power reactor waste by-product. }\end{array}$ \\
\hline Sr-90 & Moderate & $\begin{array}{l}\text { Beta particle source with } 2.27 \mathrm{MeV} \text { maximum energy of daughter } \\
\text { Y- } 90 \text {. Moderate } 28 \text { year half-life. Power reactor waste by } \\
\text { product. }\end{array}$ \\
\hline $\mathrm{Ni}-63$ & Moderate & $\begin{array}{l}\text { Beta particle source with very low } 0.067 \mathrm{MeV} \text { maximum energy } \\
\text { and no gamma rays. Long } 100 \text { year half-life. }\end{array}$ \\
\hline T1-204 & Moderate & $\begin{array}{l}\text { Beta particle source with } 0.77 \mathrm{MeV} \text { maximum energy. Short } 3.8 \\
\text { year half-life. }\end{array}$ \\
\hline C-14 & Low & $\begin{array}{l}\text { Beta particle source with } 0.159 \mathrm{MeV} \text { maximum energy. Long } \\
5730 \text { year half-life. Power reactor waste by-product. }\end{array}$ \\
\hline $\mathrm{Pm}-147$ & Low & $\begin{array}{l}\text { Beta particle source with } 0.23 \mathrm{MeV} \text { maximum energy. Short } 2.6 \\
\text { year half-life. Power reactor waste by-product. }\end{array}$ \\
\hline \multirow[t]{2}{*}{ Ru-106 } & Low & $\begin{array}{l}\text { Beta particle source with } 3.6 \mathrm{MeV} \text { maximum energy of daughter } \\
\text { Rh-106. Short } 1.0 \text { year half-life. }\end{array}$ \\
\hline & & Low energy photon emitters \\
\hline Cd-109 & High & $\begin{array}{l}\text { Photon source with } 22 \mathrm{keV} \text { energy. Acceptably long } 1.2 \text { year half } \\
\text { life. }\end{array}$ \\
\hline $\mathrm{Fe}-55$ & High & Photon source with $6 \mathrm{keV}$ energy. Moderate 2.6 year half-life. \\
\hline Sr-90/Al & Moderate & $\begin{array}{l}\text { Photon source with } 60-150 \mathrm{keV} \text { bremsstrahlung energy. Long } 28 \\
\text { year half-life. }\end{array}$ \\
\hline Am-241 & Moderate & $\begin{array}{l}\text { Photon source with } 60 \mathrm{keV} \text { energy. Very long } 433 \text { year half-life } \\
\text { Useful for steel thickness measurements to } 10 \mathrm{~mm} \text {. }\end{array}$ \\
\hline $\mathrm{H}-3 / \mathrm{Zr}$ & Moderate & $\begin{array}{l}\text { Photon source with } 5-9 \mathrm{keV} \text { bremsstrahlung energy. Long } 12.3 \\
\text { year half-life. }\end{array}$ \\
\hline Pu-238 & Low & Photon source with $12-17 \mathrm{keV}$ energy. Long 86 year half-life. \\
\hline $\mathrm{Pb}-210$ & Low & Photon source with $47 \mathrm{keV}$ energy. Long 22 year half-life. \\
\hline Tm-170 & Low & Photon source with $84 \mathrm{keV}$ energy. Short 0.35 year half-life. \\
\hline \multirow[t]{2}{*}{$\mathrm{Pm}-147 / \mathrm{Al}$} & Low & $\begin{array}{l}\text { Photon source with } 12-45 \mathrm{keV} \text { bremsstrahlung energy. Moderate } \\
2.6 \text { year half-life. }\end{array}$ \\
\hline & & High energy photon emitters \\
\hline $\mathrm{Co}-60$ & Moderate & $\begin{array}{l}\text { Photon source with } 1200-1300 \mathrm{keV} \text { energy. Long } 5.3 \text { year half- } \\
\text { life. Useful for steel thickness measurements to } 150 \mathrm{~mm} \text {. }\end{array}$ \\
\hline Cs-137 & Low & $\begin{array}{l}\text { Photon source with } 660 \mathrm{keV} \text { energy. Long } 30 \text { year half-life. } \\
\text { Useful for steel thickness measurements to } 100 \mathrm{~mm} \text {. }\end{array}$ \\
\hline
\end{tabular}




\section{Radiography}

Industrial radiography plays a very central role in assuring public safety by nondestructively examining welds and searching for flaws in pressure vessels, piping, bridges, airplanes, ships, etc. The major radioisotopes in radiography are summarized in Table 4. Two radioisotopes, Ir-192 and Co-60, are the leaders in gamma radiography. While Co-60 has more penetrating radiation that permits radiography of thicker sections, the sources need shielding that makes them larger and bulkier. In contrast, the lower energy gamma rays and very high specific activity of Ir-192 have allowed much more portable gamma radiography equipment to become widespread. A very significant (3:1) premium is paid per curie for Ir-192 over Co-60. Some inroads are being made into the use of these radioisotopes by compact, field deployable accelerator sources.

Table 4. Major Radioisotopes in Radiography.

\begin{tabular}{|c|c|c|}
\hline Radioisotope & Relative Use & Comments \\
\hline $\mathrm{Co}-60$ & High & $\begin{array}{l}\text { High energy spectrum. Optimum thickness of steel sections is } 50 \text { - } \\
150 \mathrm{~mm} \text {, or } 150-450 \mathrm{~mm} \text { for light alloys. Source sizes up to } 2,000 \\
\text { curies. }\end{array}$ \\
\hline Ir-192 & High & $\begin{array}{l}\text { Moderate energy spectrum. Optimum thickness of steel sections is } \\
12-62 \mathrm{~mm} \text {, or } 40-190 \mathrm{~mm} \text { for light alloys. Source sizes up to } 200 \\
\text { curies. Sources more portable than Co- } 60 \text {. }\end{array}$ \\
\hline $\mathrm{Yb}-169$ & Moderate-Low & $\begin{array}{l}\text { Alternative to } \mathrm{Tm}-170 \text {. Relatively short half life means sensitivity } \\
\text { to supply, and use for one-time projects only. }\end{array}$ \\
\hline Tm-170 & Low & $\begin{array}{l}\text { Lower energy spectrum better suited to thin sections of light alloys. } \\
\text { Optimum thickness of steel sections is } 3-13 \mathrm{~mm} \text {, or } 8-37 \mathrm{~mm} \text { for } \\
\text { light alloys. Source sizes up to } 35,000 \text { curies. Relatively low } \\
\text { specific activity means very large source size. }\end{array}$ \\
\hline Cs-137 & Low & Alternate to $\mathrm{Co}-60$ sources. \\
\hline $\mathrm{Sb}-124$ & Very Low & $\begin{array}{l}\text { Alternate to Ir-192 sources. Less favorable specific activity than } \\
\text { Ir-192 due to lower cross sections and natural abundance. }\end{array}$ \\
\hline Cf-252 & Low & $\begin{array}{l}\text { Source for neutron radiography used in aircraft industry. Sources } \\
\text { are typically } 1 \text { microcurie to } 1 \text { millicurie. }\end{array}$ \\
\hline $\mathrm{Co}-58$ & Emerging & $\begin{array}{l}\text { Positron source with reasonably long half-life and specific activity. } \\
\text { Used in positron microscope studies to examine structure and flaws } \\
\text { in semiconductors, crystals, etc., and bonding of coatings or thin } \\
\text { laminates. }\end{array}$ \\
\hline
\end{tabular}

Beyond these two major radioisotopes, a few others deserve mention. For imaging thinner sections and/or lower atomic weight materials, radioisotopes with lower energy spectra are better. These include $\mathrm{Yb}-169$ and $\mathrm{Tm}-170$. The market for these is small, however. The alternate radioisotopes to Co-60 and Ir-192, Cs-137 and Sb-124 
respectively, do not seem to have made any inroads. For neutron radiography, Cf-252 is included in Table 4.

Product integrity and structure can also be studied with electrons and positrons. While very widespread, electron microscopy is outside the scope of this work. Positron microscopy offers a unique method that is especially sensitive to atomic defects for investigating a material, and several isotopes have been used. These are $\mathrm{Na}-22$, an accelerator-produced radioisotope with a long half-life, and Co-58, a reactor-produced radioisotope with a fairly short 71 day half-life and four times less abundant positron emission. The supply and quality of $\mathrm{Na}-22$ have been irregular, and research users of $\mathrm{Na}$ 22 are willing to make the modifications to their equipment in order to use Co-58. Overall, it is felt that Co-58 can compete with Na-22 if it can be shown that the supply is reliable.

\section{Analytical Measurements}

Radioisotope instruments have been developed for a number of chemical, elemental, or physical analyses of material samples. The major uses are $x$-ray fluorescence measurements, electron capture detectors, neutron activation analyses, and Mössbauer spectrometry. The first two employ reactor-produced radioisotopes. The last two employ either transuranic radioisotopes like Cf-252 or Am-241/Be, or accelerator-produced isotopes like Co-57, and are not discussed further.

$\mathrm{X}$-ray fluorescence relies very generally on the ability to excite and detect characteristic $\mathrm{x}$-rays of elements by exposing them to $\mathrm{x}$-rays. Across the periodic table, the energies of the characteristic $\mathrm{x}$-rays are very low for the light elements, and moderately high for the heavier elements. Accordingly, a range of photon sources are required, depending upon the elements one needs to detect. At the light end, Fe-55 is popular because it has a lowenergy $(6 \mathrm{keV})$ photon and can detect elements as light as aluminum with an atomic number of 13. In the middle range, Cd-109 is popular as a $22 \mathrm{keV}$ source that detects elements with atomic numbers from 26 to 42 and from 60 to 90 . These and other radioisotopes are presented in the summary in Table 5. Source sizes required range from 1 millicurie to 1 curie. Aside from the energy of the photon emitted, other considerations are important in instrument design, such as having a high specific activity to reduce the source size and self-shielding. Generally a specific activity of 2-5 curies per gram of $\mathrm{Cd}$ 109 is considered adequate for $\mathrm{x}$-ray fluorescence equipment. This is considerably lower than the 100 curies per gram required for a medical $\mathrm{Ag}-109 \mathrm{~m}$ generator, stemming from a limit on toxic cadmium breakthrough. 
Electron capture detectors exploit the electron affinity of various compounds such as poisons, explosives, insecticides, and other hazards. The radioisotope is simply a constant source of electrons providing a steady leakage current. As the compound absorbs electrons and interrupts the current, it is detected. The sensitivity of electron capture detectors is enormous. The isotope of choice is Ni-63 with a source size of about 10 millicuries, with some usage of $\mathrm{H}-3, \mathrm{Fe}-55$ and others as well. Fe-55 can be produced in a relatively small cyclotron, while reactor production is dependent upon a scarce and expensive supply of Fe-54.

Table 5. Major Radioisotopes in Analytical Measurements.

\begin{tabular}{|c|c|c|}
\hline Radioisotope & Relative Use & Comments \\
\hline $\mathrm{Fe}-55$ & Moderate & $\begin{array}{l}\text { Photon source with } 6 \mathrm{keV} \text { energy. Moderate } 2.6 \text { year half-life. } \\
\text { Excites } \mathrm{K} \mathrm{x} \text {-rays of } \mathrm{Al}-\mathrm{Cr} \text { and } \mathrm{L} \mathrm{x} \text {-rays of } \mathrm{Br}-\mathrm{Xe} \text {. }\end{array}$ \\
\hline $\mathrm{Pu}-238$ & Low & $\begin{array}{l}\text { Photon source with } 12-17 \mathrm{keV} \text { energy. Long } 86 \text { year half-life. } \\
\text { Excites } \mathrm{K} \text { x-rays of Mn-Y and L X-rays of Eu-Bi. }\end{array}$ \\
\hline Cd-109 & Moderate & $\begin{array}{l}\text { Photon source with } 22 \mathrm{keV} \text { energy. Acceptable } 1.2 \text { year half-life. } \\
\text { Excites } \mathrm{K} \mathrm{x} \text {-rays of Fe-Mo and L x-rays of Nd-Th. }\end{array}$ \\
\hline Am-241 & Moderate & $\begin{array}{l}\text { Photon source with } 60 \mathrm{keV} \text { energy. Very long } 433 \text { year half-life. } \\
\text { Excites } \mathrm{K} \text { x-rays of I-Lu. As a neutron source, typically } 1 \text { to } 100 \\
\text { curies of Am-241 are combined with a Be converter. }\end{array}$ \\
\hline $\mathrm{Co}-57$ & Low & $\begin{array}{l}\text { Photon source with } 122 \text { and } 136 \mathrm{keV} \text { energy. Short } 0.7 \text { year half- } \\
\text { life. Accelerator produced radioisotope. Excites K X-rays of Hg-U. } \\
\text { Important Mössbauer effect source. }\end{array}$ \\
\hline Gd-153 & Low-Moderate & $\begin{array}{l}\text { Photon source with } 42 \mathrm{keV} x \text {-ray spectrum and several } 100 \mathrm{keV} \\
\text { gamma rays. Relatively short } 0.66 \text { year half-life. Excites x-rays of } \\
\text { heavier elements up to Fr. }\end{array}$ \\
\hline $\mathrm{Ni}-63$ & Moderate & $\begin{array}{l}\text { Pure beta emitter with } 67 \mathrm{keV} \text { maximum energy and long } 100 \text { year } \\
\text { half-life. Very desirable for electron capture detectors. }\end{array}$ \\
\hline T1-204 & Moderate & $\begin{array}{l}\text { Pure beta emitter with } 770 \mathrm{keV} \text { maximum energy and moderate } 3.8 \\
\text { year half-life. }\end{array}$ \\
\hline
\end{tabular}

\section{Radiation Processing}

Radiation processing applications are almost the exclusive domain of large Co-60 sources. Major radioisotopes in radiation processing are shown in Table 6. The two dominant applications are medical product sterilization and food irradiation. Inroads are being made on the dominance of Co- 60 by electron accelerators. The use of Cs- 137 sources is small in this application, probably because incidents with leakage from Cs-137 sources have led to their reputation as a risky technology. 
A minor market in radiation processing exists for anti-static treatment. Typically, a large alpha-emitting source is plated on a long surface and placed next to a continuous rolling paper or plastic sheet to discharge the static electricity built up in processing.

Table 6. Major Radioisotopes in Radiation Processing.

\begin{tabular}{ccl}
\hline $\begin{array}{c}\text { Radioisotope } \\
\text { Co-60 }\end{array}$ & $\begin{array}{c}\text { Relative Use } \\
\text { Very High }\end{array}$ & $\begin{array}{l}\text { Comments } \\
\text { High energy spectrum. Source sizes in the range of } 0.1-4 \text { million } \\
\text { curies. Source replacement needed every 2-3 years due to } 5.3 \text { year } \\
\text { half-life. }\end{array}$ \\
Cs-137 & Low & $\begin{array}{l}\text { Alternate to Co-60 sources. Source replacement only needed every } \\
10-15 \text { years due to } 30 \text { year half-life. } \\
\text { Alpha emitter used to control static electricity buildup in paper and } \\
\text { plastics processing. }\end{array}$ \\
\hline
\end{tabular}

There are now about 150 gamma-ray irradiation facilities for radiation sterilization of medical products used in over 40 countries. Their collective source strength is about 125 million curies of Co-60. There are only about 20 electron accelerators employed in the same application. Electron accelerators with energies of about $5-10 \mathrm{MeV}$ and throughput of 5-150 kW are used for sterilization. At $10 \mathrm{MeV}$, essentially $100 \%$ of all disposable medical products can potentially be sterilized, so there is no need to achieve higher energies, just higher throughput.

There are now about 30 commercial food irradiation plants in 25 countries. Projections are for growth to 80 plants in 40 countries by the late 1990s. Most plants are capable of handling both medical products and food. When applied to food irradiation, electron accelerators are usually only effective on thin layers of food; Co-60 sources are used for bulk food products packaged in boxes. Some accelerators use high atomic number converter plates to generate bremsstrahlung $\mathrm{x}$-rays, but the conversion efficiency is not very favorable (being only about $5 \%$ for $5 \mathrm{MeV}$ electrons). There is an upper $5 \mathrm{MeV}$ limit to the energy of radiation permitted in food irradiation. This is due to the photoneutron threshold reactions in hydrogen, oxygen, and carbon which begin to appreciably activate the food above this energy.

Foods currently approved for irradiation in the U.S. include flour, fruit, potatoes, poultry, spices, vegetable seasonings, and wheat. The doses required for food irradiation are generally much less than those required for medical product sterilization.

Both Co-60 and electron beam sources have been applied in a number of large pilot projects for natural drinking water and wastewater sterilization. However, the cost has 
not generally compared favorably to alternative chemical treatments. Electron beams are under investigation for treatment of flue gases to convert $\mathrm{NO}_{\mathrm{x}}$ products radiolytically, and this application seems promising.

\section{Heat and Lighting Sources}

Radioisotope markets for isotopic heat or power sources have generally been on the decline for the past several decades. Initially boosted by major roles in the space nuclear (especially SNAP) and artificial heart programs, the use of radioisotopes has generally subsided to two uses: Power sources for deep space missions using Pu-238, and power sources for remote military intelligence sensors using Sr-90/Y-90. In general, radioisotope power sources have suffered from poor public acceptance; questions of launch safety for Pu-238 and potential environmental contamination with Sr-90 sources have continued to retard these two applications. A summary of these and other radioisotopes extensively studied by the federal government in the past is presented in Table 7. Most of the radioisotopes are fission products available from spent fuel reprocessing. A few heat source radioisotopes with desirable qualities are reactorproduced, but these are not likely to enjoy a great demand over the fission product isotopes.

Radioisotope markets for lighting sources have not grown as quickly as predicted, having suffered from a widely publicized incident in 1979 involving a chronic tritium release from an industrial manufacturer of lighting sources. A summary of the major radioisotopes for lighting is found in Table 7. The radioisotopes are divided into two major categories: Those emitting beta particles that directly activate phosphors, and those used in low voltage lamps. The first type are fully self-powered lights-a typical example is the tritium-powered runway safety lighting at airfields. The second type affords cheap, low-power lamps-a typical example is the ubiquitous krypton-excited 'power-on' lamp in consumer products. Undoubtedly the direct evidence of public safety and convenience have had much to do with continued public acceptance of radioisotopes in lighting applications. Although $\mathrm{Kr}-85$ has been supplied in fairly large quantities from spent fuel operations at Hanford (1500 curies per year at $\$ 120$ per curie), that supply was shut down several years ago. Sales of H-3 from DOE were stopped several years ago in response to growing sensitivity to the lack of a major tritium supply for the U.S. nuclear arsenal, although the sales amounted to only a fraction of the projected needs. Sales by the DOE prior to this were about 250,000 curies per year at $\$ 3$ per curie. 


\begin{tabular}{|c|c|c|}
\hline Radioisotope & Relative Use & Comments \\
\hline & & Heat and Power Sources \\
\hline $\mathrm{Pu}-238$ & High & $\begin{array}{l}\text { Transuranic isotope power source. Long half-life of } 87.4 \text { years, } \\
\text { moderate specific power of } 0.56 \text { watts/g, and low shielding } \\
\text { requirements (if kept free of impurities) are optimally suited for } \\
\text { deep space missions. Difficult to produce. }\end{array}$ \\
\hline Sr-90/Y-90 & Moderate & $\begin{array}{l}\text { Fission product isotope power source. High energy of beta } \\
\text { particles requires massive shielding, especially hindering the } \\
\text { design of smaller units. Long } 28 \text { year half-life, and has a high } \\
\text { specific activity of } 0.96 \text { watts/g. }\end{array}$ \\
\hline Pm-147 & Low & $\begin{array}{l}\text { Only fission product that can be a lightly shielded isotope power } \\
\text { source. Good specific power of } 0.333 \text { watt/g. Moderate } 2.6 \text { year } \\
\text { half-life. }\end{array}$ \\
\hline $\mathrm{Tm}-170$ & Low & $\begin{array}{l}\text { Non-fission product isotope power source. Short } 4.3 \text { month half- } \\
\text { life, but high specific power of } 3 \text { watts/g. }\end{array}$ \\
\hline Po-210 & Very Low & $\begin{array}{l}\text { Non-fission product isotope power source. Short } 4.5 \text { month half- } \\
\text { life, but extremely high specific power of } 144 \text { watts/g. Difficult to } \\
\text { produce due to low radiative capture cross section. }\end{array}$ \\
\hline \multirow[t]{2}{*}{$\mathrm{Tm}-171$} & Very Low & $\begin{array}{l}\text { Proposed isotope power source, especially for artificial hearts. } \\
\text { Very difficult to produce due to need for double neutron capture. } \\
\text { Moderate } 1.9 \text { year half-life, and reasonable specific activity of } 0.2 \\
\text { watts/g. Very little shielding required. }\end{array}$ \\
\hline & & Lighting - Phosphor activation \\
\hline $\mathrm{Kr}-85$ & High & $\begin{array}{l}\text { Beta particle source with } 670 \mathrm{keV} \text { maximum energy. Moderate } \\
10.6 \text { year half-life. Power reactor waste by-product. Specific } \\
\text { power of } 0.6 \text { watts/g. }\end{array}$ \\
\hline $\mathrm{H}-3$ & High & $\begin{array}{l}\text { Beta particle source with } 19 \mathrm{keV} \text { maximum energy. Long } 12.3 \\
\text { year half-life. Specific power of } 0.33 \text { watts } / \mathrm{g} \text {. }\end{array}$ \\
\hline \multirow[t]{2}{*}{ Pm-147 } & Low & $\begin{array}{l}\text { Beta particle source with } 230 \mathrm{keV} \text { maximum energy. Short } 2.6 \\
\text { year half-life. Power reactor waste by-product. Specific power of } \\
0.34 \text { watts/g. }\end{array}$ \\
\hline & & Lighting - Gas ionization \\
\hline $\mathrm{Kr}-85$ & High & $\begin{array}{l}\text { Beta particle source with } 670 \mathrm{keV} \text { maximum energy. Moderate } \\
10.6 \text { year half-life. Power reactor waste by-product. Specific } \\
\text { power of } 0.6 \text { watts/g. }\end{array}$ \\
\hline $\mathrm{H}-3$ & High & $\begin{array}{l}\text { Beta particle source with } 19 \mathrm{keV} \text { maximum energy. Long } 12.3 \\
\text { year half-life. Specific power of } 0.33 \text { watts/g. }\end{array}$ \\
\hline Am-241 & Moderate & $\begin{array}{l}\text { Alpha particle source with } 5.5 \mathrm{MeV} \text { energy and very long } 433 \text { year } \\
\text { half-life. Specific power of } 0.1 \text { watts/g. Photon source with } 60 \\
\text { keV energy. }\end{array}$ \\
\hline
\end{tabular}




\section{Alarm Sensing}

Alarm sensing has historically been a fairly straightforward application of radioisotopes and sensors to determine conditions such as high or low setpoint levels in fluid-filled tanks, etc. It is felt that this application is largely in decline, since radioisotopes offer little advantage over increasingly robust, inexpensive electromechanical sensors. Applications typically utilized gamma emitters that could penetrate steel-walled vessels.

One particular application in alarm sensing, ionization smoke detectors, has grown very fast in recent decades. Small units typically employ a few microcuries of Am-241 or other transuranic alpha-emitters, and have been sold in the hundreds of millions. Here again, their benefits to public safety have led to high public acceptance.

\section{Radioisotope Tracers}

Many stable and radioisotope tracers have been produced over the years, especially for environmental and plant biology studies. Literally hundreds of isotopes have been used, and dozens are still popular to some degree. Almost 30 radioisotopes were listed in a comprehensive 1984 monograph: Stable isotopes included B-10, N-14, N-15, Mg-26, K$41, \mathrm{Cu}-65$, and radioactive isotopes included $\mathrm{N}-13, \mathrm{Mg}-28, \mathrm{P}-32, \mathrm{P}-33, \mathrm{~S}-35, \mathrm{Cl}-36, \mathrm{~K}-$ 40, K-42, K-43, Ca-45, Mn-54, Fe-59, Cu-64, Cu-67, Zn-65, Rb-86, Sr-85, Sr-89, Mo-99, Cs-134, and Cs-137. The 1984 prices for most of them were between $\$ 50$ and $\$ 200$ per millicurie. The only exception was $\mathrm{Cl}-36$, quoted at $\$ 1000$ per millicurie. While high flux reactors could produce virtually any of them, the quantities required are typically quite small. However, some of these such as P-32, P-33, Cu-67, Sr-89, and Cs-137 are required in much greater quantities for medical uses. Tracer uses of these radioisotopes could be supplied by small increases in production by medical radioisotope manufacturers.

Radioisotope tracers were explored extensively several decades ago for diverse industrial applications, including flow measurement with $\mathrm{Na}-24, \mathrm{Br}-82, \mathrm{H}-3, \mathrm{Ar}-41, \mathrm{Kr}-$ 85 , and Xe-133. Other related studies included leak detection, stirred reactor mixing, residence times in chemical processes, and line plugging detection. It is believed that these uses are also in decline, with the increasing performance offered by alternative flow metering and scale-model visualization techniques. 


\section{Medical Markets}

\section{Brachytherapy and External Beam Therapy}

Brachytherapy is the practice of inserting small sealed sources of radioisotopes, typically called seeds, in or near a cancerous tumor for treatment. A summary of major radioisotopes for brachytherapy appears in Table 8 . For a number of reasons discussed in the table, I-125 has become the most popular source for brachytherapy seeds.

Usually a number of seeds are implanted to achieve a relatively uniform dose to the tumor. The practice of surgically emplacing catheters or applicators near a tumor for source loading after the surgery is called "remote afterloading." Ir-192 has become a very popular radioisotope for remote afterloader systems, although Cs- 137 and Co-60 are also used. High dose rate afterloaders utilize a 10 curie source, and low dose rate afterloaders utilize a 1 curie or smaller source. Remote afterloading represented a major improvement in brachytherapy because trial dosimetry can be established before treatment, and the occupational exposure to medical workers is almost completely eliminated. High dose rate afterloaders allow rapid treatment, often on an outpatient basis, yet cost upwards of $\$ 300,000$ for the equipment. There is, however, some controversy that high dose rate afterloaders are not as effective as low dose rate afterloaders.

External beam therapy employs a variety of clinical radiation generators, including $\mathbf{x}$ ray tubes, linear accelerators, heavy particle beams, and devices using radionuclide sources. It is beyond the scope of this report to describe the great variety of generators. Radionuclide gamma-ray sources have used Ra-226, Cs-137, and Co-60, with Co-60 being by far the most commonly used radioisotope. A specific activity greater than about 200 curies per gram is routinely needed for medical Co-60 sources. 
Table 9. Major Radioisotopes in Brachytherapy.

\begin{tabular}{|c|c|c|}
\hline Radioisotope & Relative Use & Comments \\
\hline$I-125$ & High & $\begin{array}{l}\text { Very low energy spectrum. Good Ra-226 substitute for delivering } \\
\text { a localized dose. Longer-lived than Au-198, and has lower } \\
\text { shielding requirement. Relatively complex dosimetry required. } \\
\text { Sources are fairly anisotropic. }\end{array}$ \\
\hline Ir-192 & High & $\begin{array}{l}\text { Moderate energy spectrum. Good Ra- } 226 \text { substitute for delivering } \\
\text { a moderately localized dose. Lower average energy spectrum than } \\
\text { Cs- } 137 \text { or Co- } 60 \text { reduces shielding required. Adequate half-life. } \\
\text { Commonly used in remote afterloader systems. }\end{array}$ \\
\hline Cs-137 & High & $\begin{array}{l}\text { High energy spectrum. Good Ra-226 substitute for delivering a } \\
\text { non-localized dose. Clinical source life of about } 7 \text { years. }\end{array}$ \\
\hline Au-198 & Moderate & $\begin{array}{l}\text { Was a good Ra-226 substitute. Largely replaced by longer-lived I- } \\
125 \text { sources. }\end{array}$ \\
\hline Pd-103 & Moderate & $\begin{array}{l}\text { Low energy spectrum. High dose rate alternative to I-125. Less } \\
\text { anisotropy of sources than I- } 125 \text {. }\end{array}$ \\
\hline $\mathrm{Co}-60$ & Rarely used & $\begin{array}{l}\text { Was a good Ra- } 226 \text { substitute. Available with higher specific } \\
\text { activity, but more expensive than Cs- } 137 \text {. }\end{array}$ \\
\hline $\mathrm{Ra}-226$ & Rarely used & $\begin{array}{l}\text { Great historical significance because it occurs in nature and was } \\
\text { the first brachytherapy agent. Constant low-level emissions of } \\
\text { daughters were found to be themselves carcinogenic. Radon } \\
\text { hazard. Use largely discontinued. }\end{array}$ \\
\hline Sm-145 & Proposed & $\begin{array}{l}\text { Photon Activation Therapy (PAT) agent. Also suggested as a } \\
\text { replacement for } 1-125 \text {. }\end{array}$ \\
\hline
\end{tabular}

\section{Diagnostic Imaging}

Medical diagnostic imaging is certainly the paramount application of medical radioisotopes in terms of prestige and revenues. In the U.S. alone, over 36,000 nuclear medicine diagnostic procedures are performed each day. Of course, the dominant radioisotope is Tc-99m produced from Mo-99 in commercial radioisotope generators, with yearly domestic revenues of $\$ 35 \mathrm{M}$ for the bulk Mo-99 itself. The other big revenue isotopes are largely cyclotron-produced, consisting of Tl-201 and I-123, and F-18 for positron emission tomography.

Other radioisotopes in diagnostic imaging are relatively minor and are summarized in Table 9. The emerging isotopes, both Cd-109 and Os-191, are difficult to produce. Cd109 for medical applications needs to be much higher specific activity (100 curies per gram) than can be produced in high flux thermal reactors; it is typically produced in a large accelerator at great expense. Os-191 is essentially just a research isotope at this time. 
Table 9. Selected Radioisotopes in Diagnostic Imaging.

\begin{tabular}{|c|c|c|}
\hline Radioisotope & Relative Use & Comments \\
\hline Tc-99m & Dominant & $\begin{array}{l}\text { Extremely popular radioisotope. Low patient dose, optimum } \\
\text { gamma energy, ease of preparation with radioisotope generators, } \\
\text { and acceptably short half-life have all contributed to its success. } \\
\text { Despite its less than ideal chemistry, many ligands have been } \\
\text { developed with specificity for a variety of imaging modalities. }\end{array}$ \\
\hline T1-201 & Very High & Popular cardiac imaging isotope produced in cyclotrons. \\
\hline $\mathrm{I}-123$ & Very High & $\begin{array}{l}\text { Popular imaging isotope produced in cyclotrons. Iodination } \\
\text { chemistry is very well established and flexible. Has replaced I-131 } \\
\text { for imaging due to its extremely low patient dose relative to other } \\
\text { iodine isotopes. }\end{array}$ \\
\hline F-18 & High & $\begin{array}{l}\text { Popular positron emission tomography (PET) imaging isotope } \\
\text { produced in cyclotrons. Has emerged as a result of chronic } \\
\text { shortages of enriched stable isotopes used to produce other PET } \\
\text { radioisotopes. }\end{array}$ \\
\hline Se-75 & Low & $\begin{array}{l}\text { Largely replaced by Tc- } 99 \mathrm{~m} \text {. Chemistry is very favorable (can } \\
\text { covalently bond to ligands). Still useful in some studies of the } \\
\text { pancreas and brain, among others. }\end{array}$ \\
\hline Yb-169 & Low & $\begin{array}{l}\text { Useful for cistemography (imaging of the cerebrospinal fluid } \\
\text { volumes). }\end{array}$ \\
\hline Cd-109/Ag-109m & Emerging & $\begin{array}{l}\text { Ultrashort half-life ( } 40 \mathrm{~s} \text { ) useful for studies of physiologic } \\
\text { functions with a short time scale. Also used in pediatric imaging. }\end{array}$ \\
\hline Os-191/Ir-191m & Proposed & $\begin{array}{l}\text { Ultrashort half-life }(5 \mathrm{~s}) \text { useful for studies of physiologic functions } \\
\text { with a short time scale. }\end{array}$ \\
\hline Gd-153 & Obsolete & $\begin{array}{l}\text { Briefly the radioisotope of choice for bone densitometry } \\
\text { measurements using dual photon absorptiometry (DPA), needed } \\
\text { for studies of osteoporosis. }\end{array}$ \\
\hline Sm-153 & Obsolete & $\begin{array}{l}\text { Alternate radioisotope for DPA-has same daughter } \mathrm{x} \text {-rays as Gd- } \\
153 \text {, but has a beta decay in addition. Short half-life required } \\
\text { weekly changeout of densitometer sources. }\end{array}$ \\
\hline
\end{tabular}

\section{In-vitro Studies}

Radiolabeled immunoassays are among the most commonly applied medical analytical techniques and are central to many medical diagnoses. Radioisotopes that have been used in radioimmunoassays include $\mathrm{H}-3, \mathrm{C}-14, \mathrm{Co}-57$, Se-75, I-125, and I-131. Of these, the most commonly used ones today are $\mathrm{I}-125, \mathrm{Co}-57$, and $\mathrm{H}-3$; more than $90 \%$ of all such laboratory tests utilize I-125, however. Beside medical use, these techniques can also be applied to the determination of environmental pollutants such as herbicides and pesticides to concentrations as low as $10^{-14}$ molar in some cases. While other alternative 
labeling schemes exist, and in some cases are more sensitive, the radiolabeled assays are generally the most robust and free of interfering effects.

\section{Unsealed Source Therapies}

Unsealed source therapies are divided into three broad categories. First are radioisotopes used in arthritis therapy. Some six million Americans suffer from rheumatoid arthritis. Of these, about $50 \%$ involve the knee joint and $80 \%$ involve the hand, with smaller involvement of the hip, shoulder, wrist, etc. Chronic inflammation of the synovial tissues (i.e., lining) of the joint can lead to eventual destruction of the cartilage. Aside from treatment with ethical drugs which are not always effective, two forms of excising the synovial tissues exist-surgical and radiation synovectomy. The currently preferred radionuclide for radiation synovectomy is Dy-165, which has surpassed the use of Er-169, Re-186, P-32, Au-198, and Y-90 for this treatment. Ho-166 offers potential advantages over Dy-165 in (1) the energies of radiation emitted, (2) the improved properties of the colloid preparation, and (3) the longer half-life. Of these, the half-life is especially important, since Dy- 165 therapy involves travel to special facilities near its point of origin because of its 2.3 hour half-life, versus 27 hours for Ho-166. A summary is presented in Table 10.

Table 10. Major Radioisotopes in Arthritis Therapy.

\begin{tabular}{|c|c|c|}
\hline Radioisotope & Relative Use & Comments \\
\hline Au-198 & Declining & Prepared as colloidal suspension for radiation synovectomy. \\
\hline Dy-165 & Growing & $\begin{array}{l}\text { Best choice radioisotope for radiation synovectomy, but difficult to } \\
\text { produce. More efficacious than Au- } 198 \text {. }\end{array}$ \\
\hline Ho-166 & Growing & Alternate for Dy-165 therapy. More effective than Au-198. \\
\hline $\operatorname{Re}-188$ & Proposed & \\
\hline Sm-153 & Proposed & \\
\hline
\end{tabular}

Second in the category are radioimmunotherapies, where a therapeutic dose is delivered to a cancerous tumor by labeling a cell-killing radioisotope onto a monoclonal antibody whose uptake is very strong in the tumor. A summary of currently used radioisotopes is presented in Table 11. Ideally, the half-life of the radioisotope should be roughly equal to the uptake and residence time of the monoclonal antibody. It should be noted that this therapy is relatively new and in many cases unproved. Considerable research effort is being undertaken to bring this therapy to real clinical use. 
Table 11. Major Radioisotopes in Radioimmunotherapy.

\begin{tabular}{|c|c|c|}
\hline Radioisotope & Relative Use & Comments \\
\hline P-32 & Declining & $\begin{array}{l}\text { Still popular radioisotope, with many old-line advocates. No } \\
\text { useful gamma ray for imaging. }\end{array}$ \\
\hline $\mathrm{Cu}-67$ & Growing & $\begin{array}{l}\text { Radiation cascade is known to be highly lethal to cells. Has a } \\
\text { useful gamma ray for imaging. Cu- } 64 \text { has similar properties, but } \\
\text { has a shorter half life. }\end{array}$ \\
\hline $\operatorname{Re}-186$ & Growing & $\begin{array}{l}\text { Chemical analog of technetium that can take advantage of ligands } \\
\text { developed for Tc- } 99 \mathrm{~m} \text {. In a sense, if you can image the tumor with } \\
\text { Tc- } 99 \mathrm{~m} \text {, then you can treat it with } \mathrm{Re}-186 \text { (or Re-188). Has a } \\
\text { useful gamma ray for imaging. }\end{array}$ \\
\hline W-188/Re-188 & Proposed & $\begin{array}{l}\text { Alternate to Re-186 with a shorter half life and more energetic } \\
\text { beta. Has a useful gamma ray for imaging. }\end{array}$ \\
\hline P-33 & Proposed & $\begin{array}{l}\text { Alternate to P-32 with much lower energy beta for more localized } \\
\text { dose distribution. No useful gamma ray for imaging. }\end{array}$ \\
\hline Ho-166 & Proposed & \\
\hline Sm-153 & Proposed & \\
\hline Sm-145 & Proposed & \\
\hline
\end{tabular}

The third major area of unsealed source therapy is for bone cancer pain relief, and ultimately, bone cancer therapy. Bone metastases develop in more than $50 \%$ of patients with lung, breast, or prostate cancer, and often lead to progressive bone pain. There are about 1 million new cases of cancer each year, and about $50 \%$ of all patients dying of cancer have skeletal metastases at the time of death, making the demand for this therapy very high. Relatively new radiotherapies include Sr-89, Re-186, and Sm-153. The latter two have theoretical advantages over Sr-89. The first treatment of bone pain began over 40 years ago with P-32, which is still widely used. Other radioisotopes either tested or proposed for bone pain palliation include As-76, Ho-166, I-131, P-33, Re-188, Sn-117m, and Y-90. A summary of radioisotopes is shown in Table 12.

Beyond the goal of palliation, $\mathrm{Sn}-117 \mathrm{~m}$ has been proposed as a therapy for bone cancer. Its conversion electrons, with a range of approximately $0.2 \mathrm{~mm}$ in water, can impart a highly localized radiation dose. When delivered to bone mineral, the short range of the conversion electrons should be much more sparing of sensitive marrow than high energy beta emission from isotopes such as P-32, Sr-89, and others with ranges on the order of 1 $\mathrm{cm}$. The radiopharmaceutical $117 \mathrm{~m}\left(\mathrm{Sn}^{4+}\right) \mathrm{DTPA}$ is the preparation of choice. Preliminary studies in patients have proven efficacy of pain relief. The limiting toxicity will be associated with the DTPA and not the radioisotope; this may very well be sufficient to deliver a therapeutic dose to the bone metastases. 
Table 12. Major Radioisotopes in Bone Cancer Pain Relief.

\begin{tabular}{|c|c|c|}
\hline Radioisotope & Relative Use & Comments \\
\hline Sr-89 & Growing Rapidly & $\begin{array}{l}\text { Metastron (Amersham) approved as a new drug in the U.S. in June, } \\
\text { 1993. Has been approved in Europe for several years. Has no } \\
\text { gamma ray for imaging-imaging studies typically need to use Sr- } \\
\text { 85. Biological half-life three times longer in bone metastases than } \\
\text { in normal bone. }\end{array}$ \\
\hline $\operatorname{Re}-186$ & Growing & $\begin{array}{l}\text { Prepared as }{ }^{186} \text { Re-HEDP (Mallinckrodt). Phase II clinical trials } \\
\text { nearing completion. Provides a high-dose rate alternative to Sr- } 89 \text {, } \\
\text { which may be found more efficacious. Has a gamma ray quite } \\
\text { suitable for imaging. Rhenium chemistry very similar to } \\
\text { technetium-should enjoy wide choice of ligands developed for } \\
\text { Tc- } 99 \mathrm{~m} \text { delivery. Biological half-life only about two times longer } \\
\text { in bone metastases than in normal bone. }\end{array}$ \\
\hline Sm-153 & Growing & $\begin{array}{l}\text { Prepared as }{ }^{153} \mathrm{Sm} \text {-EDTMP. Phase II clinical trials nearing } \\
\text { completion. Has a gamma ray quite suitable for imaging. Similar } \\
\text { dose rate to Re-186, but permits treatment on an outpatient basis. }\end{array}$ \\
\hline $\mathrm{Sn}-117 \mathrm{~m}$ & Proposed & $\begin{array}{l}\text { Prepared as } 117 \mathrm{mSn} \text {-DTPA. Dose (mainly derived from } \\
\text { conversion electrons) is very highly localized, which may spare the } \\
\text { bone marrow. Difficult to produce this radioisotope with high } \\
\text { specific activity. Has a gamma ray quite suitable for imaging. }\end{array}$ \\
\hline P-32 & Declining & $\begin{array}{l}\text { Prepared as sodium orthophosphonate (Mallinckrodt). Prevalent } \\
\text { use since the } 1940 \text { s. Considerable side effects. Many problems } \\
\text { with dosimetry over the years due to carryover into other organs- } \\
\text { dose discrepancies have been as high as five-fold. }\end{array}$ \\
\hline W-188/Re-188 & Proposed & Very high dose rate alternative to $\mathrm{Sr}-89$ and $\mathrm{Re}-186$. \\
\hline Ho-166 & Proposed & High dose rate altemative to $\mathrm{Sr}-89$. \\
\hline
\end{tabular}

\section{In-vivo Studies}

Studies involving direct introduction of radioisotopes into patients other than for therapy or imaging are classed as in-vivo studies. These include examples such as lung ventilation studies using Xe-133, blood pool volume determinations using $\mathrm{Cr}-51$ or $\mathrm{Fe}$ 59 , renal clearance and function studies, and so on. The most important factor in the choice of radioisotope is its physical and chemical compatibility: inert gases for ventilation studies, chemicals that bind to red blood cells such as iron or chromium, etc. Of course, the radioisotope delivering the lowest dose is highly preferred.

The market for in-vivo study radioisotopes is considered to be fairly small and to have a number of fission product isotopes that are already the well-established choices. 
J. Ayala, "Comparative Investigation of Radioactive Sources for the Electron Capture Detector," J. Chromatography, Vol. 195, No. 1, pp. 1-16, July 4, 1980.

C. Bomford, I. Kunkler, and S. Sherriff, Walter and Miller's Textbook of Radiotherapy, Fifth Ed., Edinburgh, Churchill Livingstone, 1993.

E. Browne, and R. Firestone, Table of Radioactive Isotopes, New York, Wiley and Sons, 1986.

J. Bushberg, J. Seibert, E. Leidholdt, and J. Boone, The Essential Physics of Medical Imaging, Williams and Wilkins, 1994.

J. Cameron, and C. Clayton, Radioisotope Instruments, Part 1, Pergamon, 1971.

E. Carmain, "The New Alchemy," Nuclear Energy, Washington, U.S. Council for Energy Awareness, pp. 12-23, Second Quarter, 1993.

A. Chan, and S. Banerjee, "Desing Aspects of Gamma Densitometers for Void Fraction Measurements in Small Scale Two-Phase Flows," Nuc. Instr. Methods Phys. Res., Vol. 190, No. 1, pp. 135-148, November 15, 1981.

R. Chandra, Introductory Physics of Nuclear Medicine, 4th Ed, Lea and Febiger, 1992.

J. Charlton, Radioisotope Techniques for Problem-Solving in Industrial Process Plants, Gulf Publishing, 1986.

P. Early, and D. Sodee, Principles and Practice of Nuclear Medicine. Second Ed., St. Louis, Mosby, 1995.

J. Eary, R. Robinson, S. Goldsmith, and E. Silberstein, "Radiopharmaceutical Therapy of Cancer Pain from Bone Metastases," Continuing Education Course on Therapy of the Pain of Osteoblastic Metastases with Unsealed Sources, Course Notes, Soc. Nuc. Med. 41st Annual Meeting, June 6, 1994.

H. Fullam, and H. Van Tuyl, "Promethium Technology: A Review," Isot. Rad. Tech., Vol. 7, No. 2, pp. 207-221, Winter, 1969-1970.

I. Goldstein, U.S. Department of Energy Isotope Production and Distribution Program Management Study, Arthur Andersen \& Co., 1993.

D. Hussey, and J. Doombos, "Radiation Therapy of Localized Prostate Cancer," Problems in Urology, Vol. 4, No. 3, pp. 420-446, September, 1990.

International Atomic Energy Agency, Vienna, Radioisotope Production and Ouality Control, Technical Report Series No. 128, 1971.

International Atomic Energy Agency, Vienna, Separation, Storage and Disposal of Krypton-85, Technical Report Series No. 199, Vienna, 1980.

International Atomic Energy Agency, Vienna, Industrial Application of Radioisotopes and Radiation Technology, Vienna, 1981.

International Atomic Energy Agency, Vienna, Guidebook on Radioisotope Tracers in Industry, Technical Report Series No. 316, Vienna, 1990. 
International Atomic Energy Agency, Vienna, Applications of Isotopes and Radiation in Conservation of the Environment, Vienna, 1992.

Isotec, Inc., Stable Isotopes for Research and Industry, 1994.

S. Jackson, I. Fogelman, G. Blake, and L. Rosenthall, Continuing Education Course on Bone Densitometry, Course Notes, Soc. Nuc. Med. 41 st Annual Meeting, June 6, 1994.

F. Khan, The Physics of Radiation Therapy,2nd Ed., Williams and Wilkins, 1994.

L. Lang, D. Deonigi, and C. Rohrmann, "Power Cost Reduction from Isotope Revenues," Nuc. Appl., Vol. 3, pp. 665-678, November, 1967.

E. Lorch, "Industrial and Analytical Application of Radioisotope Radiation Sources," J. Radioanalytical Chem., Vol. 48, pp. 209-212, 1979.

Los Alamos Meson Production Facility, Progress at LAMPE, LA-12473-PR, November, 1992.

M. L'Annunziata, and J. Legg, Isotopes and Radiation in Agricultural Sciences. Vol. 1, Academic, 1984.

M. L'Annunziata, and J. Legg, Isotopes and Radiation in Agricultural Sciences, Vol. 2, Academic, 1984.

M. L'Annunziata, Radionuclide Tracers: Their Detection and Measurement, Academic, 1987.

L. Leonard, "Radioluminescent Lighting Technology Transfer Conference," CONF-9009201, Annapolis, MD, September 25-26, 1990.

J. Machurek, and E. Fowler, "Commercial Radioisotope Production in Power Reactors," Isot. Rad. Tech., Vol. 9, No. 4, pp. 1375-378, Summer, 1972.

Management Information Services, Inc., Economic and Employment Benefits of the Use of Radioactive Materials, 1994.

S. Mirzadeh, R. Schenter, A. Callahan, and F. Knapp, "Production Capabilities in U.S. Nuclear Reactors for Medical Radioisotopes," ORNL/TM-12010, Martin Marietta Energy Systems, Inc., Nov 1992.

S. Nag, "Brachytherapy for Lung Cancer: Review," Cancer Treatment Symposia, Vol. 2, pp. 49-56, 1985.

New England Nuclear, Inc., NEN Radionuclides, July, 1989.

Nordion International, Inc., Radiochemical Catalogue, May, 1994.

G. Petersen, Personal Communication, "Radioisotope Major and Minor Leagues," July, 1994.

D. Ray, Trashing the Planet, Regnery Gateway, 1990.

G. Rayudu, ed., Radiotracers for Medical Applications, Boca Raton, CRC Press, 1983.

G. Saha, Fundamentals of Nuclear Pharmacy, 3rd Ed., Springer-Verlag, 1992.

G. Saha, Physics and Radiobiology of Nuclear Medicine, Springer-Verlag, 1993. 
R. Schenter, Personal Communication, "Application Required Radioisotopes from Reactor and Accelerator Production," June, 1994.

R. Schenter, Personal Communication, "U.S. Reactor Medical Radioisotope Market Information," July, 1994.

R. Schenter, et. al., "Radioisotope Production Technology Development Annual Report for Fiscal Year 1990," WHC-SP-0632, Westinghouse Hanford Co., Oct., 1990.

R. Schenter, et. al., "Radioisotope Production Technology Development Annual Report for Fiscal Year 1989," WHC-SP-0583, Westinghouse Hanford Co., Apr., 1990.

J. Shapiro, Radiation Protection. 3rd Ed., Harvard University Press, 1990.

S. Srivastava, Radiolabled Monoclonal Antibodies for Imaging and Therapy, Plenum, 1988.

U.S. Department of Energy, Isotope Production and Distribution, April, 1992.

U.S. Department of Energy, National Isotope Strategy, April, 1994.

Y. Wang, ed., Handbook of Radioactive Nuclides, Cleveland, OH, Chemical Rubber Co, 1969.

E. Wheelwright, Promethium Technology, American Nuclear Society, 1973

R. Woods, and A. Pikaev, Applied Radiation Chemistry: Radiation Processing, Wiley \& Sons, 1994. 